\title{
Degradace $\mathrm{Cr}_{3} \mathrm{C}_{2}-\mathrm{NiCr}$ povlaku připraveného technikou HVOF
}

\section{Degradation of $\mathrm{Cr}_{3} \mathrm{C}_{2}-\mathrm{NiCr}$ coating prepared by the HVOF technique}

\author{
Rapouch $J$. \\ Ústav kovových materiálů a korozního inženýrství, VŠCHT Praha \\ E-mail: rapouchj@vscht.cz
}

Během expozice vřetena $z$ vysokochromové oceli $X 22 \mathrm{Cr}$ MoV12-1 s HVOF povlakem na bázi $\mathrm{Cr}_{3} \mathrm{C}_{2}-\mathrm{NiCr}$ v prostředi přehřáté páry došlo po několika hodinách provozu $k$ degradaci tohoto povlaku. V této studii je hodnocena úroveň poškozeni povlaku za pomoci analýzy chemického a fázového složení na povrchu i v rezu vrstvy. V degradované i nedegradované vrstvě byly detekovány fáze $\mathrm{Ni}-\mathrm{Cr}, \mathrm{Cr}_{3} \mathrm{C}_{2}$ a $\mathrm{Cr}_{2} \mathrm{O}_{3}$. Během expozice došlo k úbytku tlouštky vrstvy o jeden řád. Pravděpodobnou přćcinou degradace vrstvy je oxidace v prostredi páry, negativní roli mohly hrát i objemné částice na rozhrani ocel/povlak.

\section{ÚVOD}

Technika HVOF (High Velocity Oxygen Fuel) je způsob povlakování, při kterém je materiál ve formě prášku pomocí nosného plynu vstřikován do spalovací komory. Zde dochází $\mathrm{k}$ natavení některých složek a výraznému urychlení pohybu směrem $\mathrm{k}$ povlakované součásti. HVOF povlaky na bázi $\mathrm{Cr}_{3} \mathrm{C}_{2}-\mathrm{NiCr}$ se používají především pro zvýšení tvrdosti a otěruvzdornosti za zvýšených teplot, kdy vykazují velmi vysokou strukturní stabilitu a odolnost proti oxidaci [1]. Zatímco matrice $\mathrm{NiCr}$ zajišt'uje povlaku dostatečnou korozní odolnost, jeho otěruvzdornost je dána primárně karbidickými částicemi. Povlak $\mathrm{Cr}_{3} \mathrm{C}_{2}-\mathrm{NiCr}$ je ve standardním stavu tvořen nanokrystalickou až amorfní matricí NiCr, karbidy, nízkým obsahem $\mathrm{Cr}_{2} \mathrm{O}_{3}$ (vzniklých prrímou reakcí chromu s kyslíkem během HVOF procesu), póry a často také malými trhlinami [2]. Nanesený HVOF povlak má vysokou hustotu a porozitu pod úrovní $1 \%$. Kromě karbidu $\mathrm{Cr}_{3} \mathrm{C}_{2}$ bývají v povlaku přítomné také karbidy $\mathrm{Cr}_{7} \mathrm{C}_{3}$ a $\mathrm{Cr}_{23} \mathrm{C}_{6}$ vzniklé transformací původního $\mathrm{Cr}_{3} \mathrm{C}_{2}$. Velkou výhodou těchto povlaků je podobný koeficient roztažnosti železa a karbidu $\mathrm{Cr}_{3} \mathrm{C}_{2}[3,4]$.

Během provozu za zvýšených teplot dochází k oxidaci a $\mathrm{v}$ povlaku se tvoří oxid $\mathrm{Cr}_{2} \mathrm{O}_{3}$. Předpokládá se,
After a few hours of operation, a $\mathrm{Cr}_{3} \mathrm{C}_{2}-\mathrm{NiCr}$-based $\mathrm{HVOF}$ coating on a spindle made of high-chromium steel $\mathrm{X} 22 \mathrm{Cr}$ MoV12-1 degraded when exposed to overheated steam. The stu$d y$ evaluates the level of coating damage by analysing chemical and phase composition on the surface and on the cross-section of the layer. $\mathrm{Ni}-\mathrm{Cr}, \mathrm{Cr}_{3} \mathrm{C}_{2}$ and $\mathrm{Cr}_{2} \mathrm{O}_{3}$ phases were detected in both degraded and non-degraded layers. During the exposure, the layer thickness thinned by an order of magnitude. The layer degradation was probably induced by oxidation in a steam environment; voluminous particles on the steel/coating interface might have played a negative role.

že $\mathrm{Cr}_{2} \mathrm{O}_{3}$ částečně zpomaluje oxidaci podkladového materiálu blokováním přístupu reaktivních složek prostředí směrem $\mathrm{k}$ podkladu [5]. Oxid $\mathrm{Cr}_{2} \mathrm{O}_{3}$ vzniká jak oxidací karbidu $\mathrm{Cr}_{3} \mathrm{C}_{2}$, tak i chromu $\mathrm{z}$ matrice povlaku. Přednostní oblastí pro difúzi kyslíku a následnou vnitřní oxidaci uvnitř povlaku jsou fázová rozhraní $\mathrm{Cr}_{3} \mathrm{C}_{2} / \mathrm{NiCr}$ [6]. K vytvoření ochranné vrstvy oxidu chromitého je třeba, aby matriční slitina NiCr obsahovala minimálně $10 \%$ Cr. Na slitině NiCr dochází během oxidace za zvýšených teplot nejdříve ke tvorbě vrstvy $\mathrm{NiO}$, pod níž se postupně vytváŕí vrstva $\mathrm{Cr}_{2} \mathrm{O}_{3}$. Reakcí těchto dvou oxidů navíc vzniká spinel $\mathrm{NiCr}_{2} \mathrm{O}_{4}$. Při vysokých koncentracích chromu v matrici je oxidická vrstva tvořena pouze $\mathrm{Cr}_{2} \mathrm{O}_{3}$ $[4,7]$. V průběhu oxidace vznikají ve vrstvě pnutí, a to tahová vlivem transformace $\mathrm{Cr}_{3} \mathrm{C}_{2}$ na karbidy $\mathrm{s}$ vyšší hustotou $\left(\mathrm{Cr}_{7} \mathrm{C}_{3}, \mathrm{Cr}_{23} \mathrm{C}_{6}\right)$, i tlaková způsobená objemovou expanzí karbidu $\mathrm{Cr}_{3} \mathrm{C}_{2}$ na oxid $\mathrm{Cr}_{2} \mathrm{O}_{3}$ (objemový poměr vzniklého $\mathrm{Cr}_{2} \mathrm{O}_{3}$ ku spotřebovanému $\mathrm{Cr}_{3} \mathrm{C}_{2}$ je asi 1,6). $\mathrm{K}$ celkovému pnutí $\mathrm{v}$ systému zároveň přispívá fakt, že oxid chromitý vzniklý oxidací karbidu $\mathrm{Cr}_{3} \mathrm{C}_{2}$ a matrice $\mathrm{NiCr}$ má vzhledem $\mathrm{k}$ odlišnému mechanismu růstu rozdílnou strukturu [6].

V literatuře nebyly zjištěny žádné negativní účinky vysokoteplotní oxidace (bez přítomnosti vodní páry) na kompaktnost a prrilnavost HVOF vrstvy. 
V prostředí vodní páry $\left(600-700{ }^{\circ} \mathrm{C}\right) \mathrm{HVOF}$ nástřik obsahující pouze slitinu $80 \mathrm{Ni}-20 \mathrm{Cr}$ nanesený na povrch oceli 9Cr-Mo1 nevykazuje výraznější degradaci. Po expozici při $750{ }^{\circ} \mathrm{C}$ po dobu $1000 \mathrm{~h}$ byla pozorována difúze železa směrem do povlaku a opačná difúze niklu z povlaku směrem do podkladového materiálu, přičemž oba procesy probíhají přibližně stejnou rychlostí [8]. $\mathrm{K}$ poškození povlaku v prostředí vodní páry může navíc přispět i př́ítomnost grafitu a mazacích olejů [9].

\section{EXPERIMENT}

Zkoumaným materiálem byla ocel X22CrMoV12-1 s HVOF nástřikem $\mathrm{Ni} 75 \mathrm{Cr} 25-\mathrm{Cr}_{3} \mathrm{C}_{2}$. Materiál byl provozně exponován v prostředí přehřáté páry $\left(580{ }^{\circ} \mathrm{C} / 15\right.$ $\mathrm{MPa})$ po dobu 21 hodin, během které došlo $\mathrm{k}$ rozpadu původního povlaku. V rámci experimentů byl hodnocen výřez vřetene opatřeného nástřrikem po provozní expozici. Vřeteno vykazovalo různé stavy povrchu (poškozený/nepoškozený). K hodnocení bylo vřeteno rozděleno na 3 části (Obr. 1):

1. Základní materiál bez povlaku (ZM),

2. HVOF vrstva krytá vodicím pouzdrem s nepoškozeným povrchem (N1),

3. HVOF vrstva před vodicím pouzdrem (tzn. nekrytá) s poškozeným povrchem (N2).

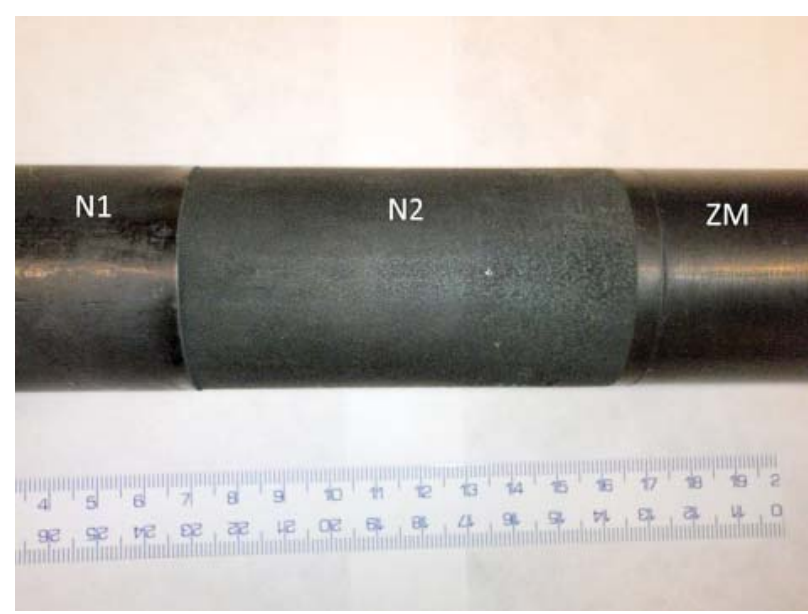

Obr. 1. Dodané vřeteno

Fig. 1. Spindle in as received state

Povrchy a metalografické výbrusy $v$ řezu vrstvy jednotlivých vzorků byly pozorovány pomocí skenovacího elektronového mikroskopu (SEM) Tescan Vega 3 vybaveného EDS analyzátorem pro chemickou analýzu.

Kromě pevných vzorků byly analyzovány i práškové vzorky seškrabané $z$ povrchu vřetene nebo odebrané z vodicího pouzdra (pravděpodobně odpadlé z povrchu vřetene v průběhu expozice). Práškové vzorky byly analyzovány metodou rentgenové fluorescenční analýzy (RFA) pro zjištění prvkového složení a rentgenové difrakční analýzy (RDA) pro detekci přítomných fází.

\section{VÝSLEDKY}

\section{Práškové vzorky}

Ve všech práškových vzorcích degradovaného nástřiku byly pomocí RDA detekovány fáze čistého $\mathrm{Ni}$ (resp. směsi Ni-Cr), karbidu $\mathrm{Cr}_{3} \mathrm{C}_{2}$ a oxidů $\mathrm{Cr}_{2} \mathrm{O}_{3}$ a $\mathrm{Fe}_{2} \mathrm{O}_{3}$ vzniklých pravděpodobně oxidací nástřiku, resp. podkladového materiálu (Tab. 1). Oxidy železa se mohly na povrch dostat také nanesením z jiné části provozního okruhu. U vzorků nánosů, které samovolně odpadly z povrchu (nalezeny v krytu kuželky), nebyla zjištěna přítomnost karbidických částic, nejspíše tak došlo $\mathrm{k}$ jejich úplné oxidaci.

Tab. 1. Fázové složení práškových vzorků odebraných z vřetene [hm. \%] / Phase composition of powder samples taken from spindle [wt. \%]

\begin{tabular}{|c|c|c|c|c|}
\hline \multirow{2}{*}{ Místo odběru } & \multicolumn{4}{|c|}{ Fáze } \\
\cline { 2 - 5 } & $\mathbf{N i}(\mathbf{N i}-\mathbf{C r})$ & $\mathbf{C r}_{\mathbf{3}} \mathbf{C}_{\mathbf{2}}$ & $\mathbf{C r}_{\mathbf{2}} \mathbf{O}_{\mathbf{3}}$ & $\mathbf{F e}_{\mathbf{2}} \mathbf{O}_{\mathbf{3}}$ \\
\hline $\mathrm{N} 1$ & 31 & 34 & 34 & - \\
\hline $\mathrm{N} 2$ & 34 & 20 & 37 & 9 \\
\hline odpadlé z povrchu & 37 & - & 49 & 14 \\
\hline
\end{tabular}

\section{Povrch vřetene}

Povrch podkladové chromové oceli (ZM) byl pokryt vrstvou magnetitu (zjištěno pomocí RDA). Kromě železa, kyslíku a chromu byly na povrchu detekovány i obsahy molybdenu a vanadu.

Povrch nástřiku s nepoškozeným povrchem (N1) byl tvořen světlejšími a tmavšími oblastmi (Obr. 2a). Na povrchu byla detekována směs chromu, niklu a kyslíku. Z hlediska fázového složení byl povrchu tvořen fázemi $\mathrm{Ni}-\mathrm{Cr}, \mathrm{Cr}_{2} \mathrm{O}_{3}$ a $\mathrm{Cr}_{3} \mathrm{C}_{2}$ zastoupených zhruba ve stejných poměrech. Jiné karbidy $\left(\mathrm{Cr}_{7} \mathrm{C}_{3}, \mathrm{Cr}_{23} \mathrm{C}_{6}\right)$ se na povrchu bud' nevyskytovaly, nebo byl jejich obsah pod mezí detekce.

Povrch degradovaného nástřiku (N2) byl také tvořen světlými a tmavými místy (Obr. 2b). Z hlediska prvkového zastoupení se tyto oblasti výrazně neliší a jsou tvořeny především chromem, niklem a kyslíkem. Metoda RDA na povrchu detekovala pouze fáze $\mathrm{Cr}_{2} \mathrm{O}_{3}$ a $\mathrm{Cr}-\mathrm{Ni}$. 


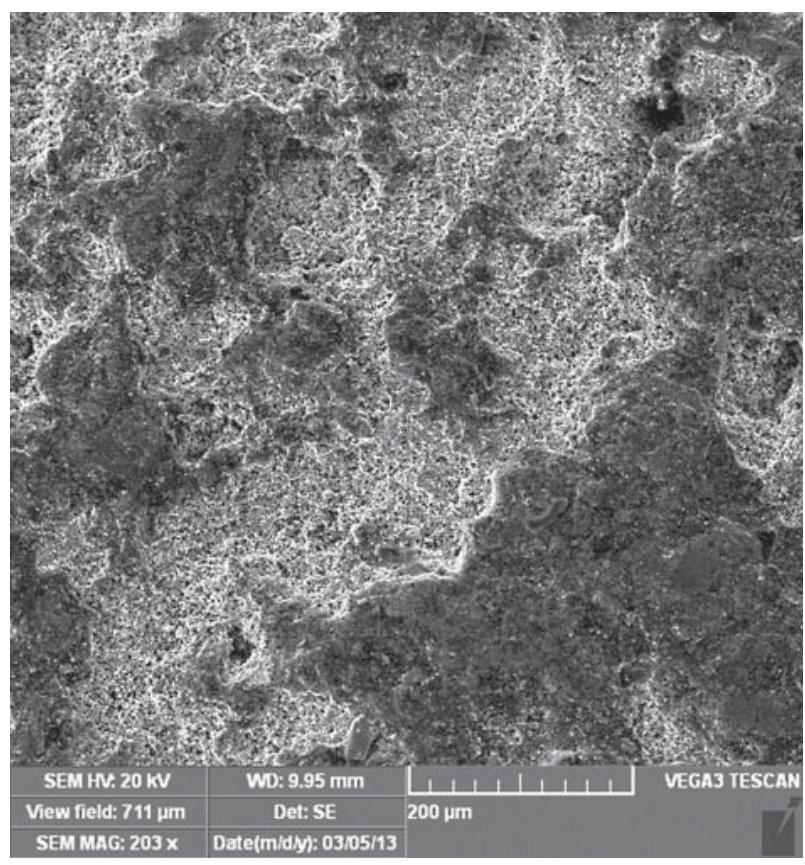

a) $\mathrm{N} 1$

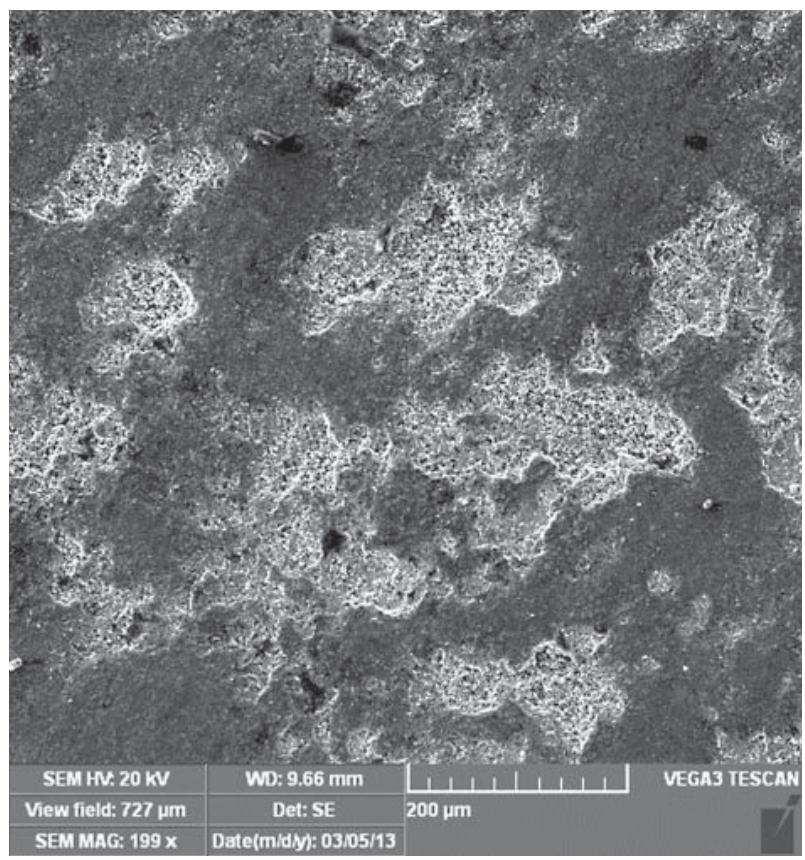

b) N2

Obr. 2. Povrch vzorků, a) N1 (pod pouzdrem), b) N2 (mimo pouzdro), SEM v zobrazení sekundárních elektronů

Fig. 2. Surface of samples, a) N1 (under bushing), b) N2 (out of bushing), SEM in secondary electrons imaging

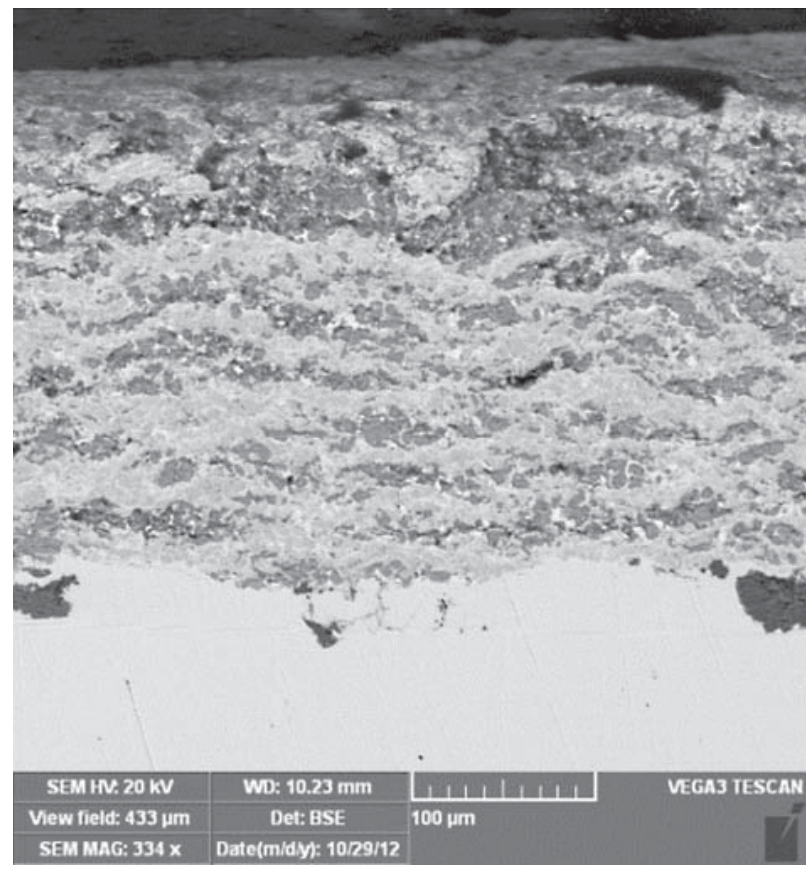

a) celkový pohled

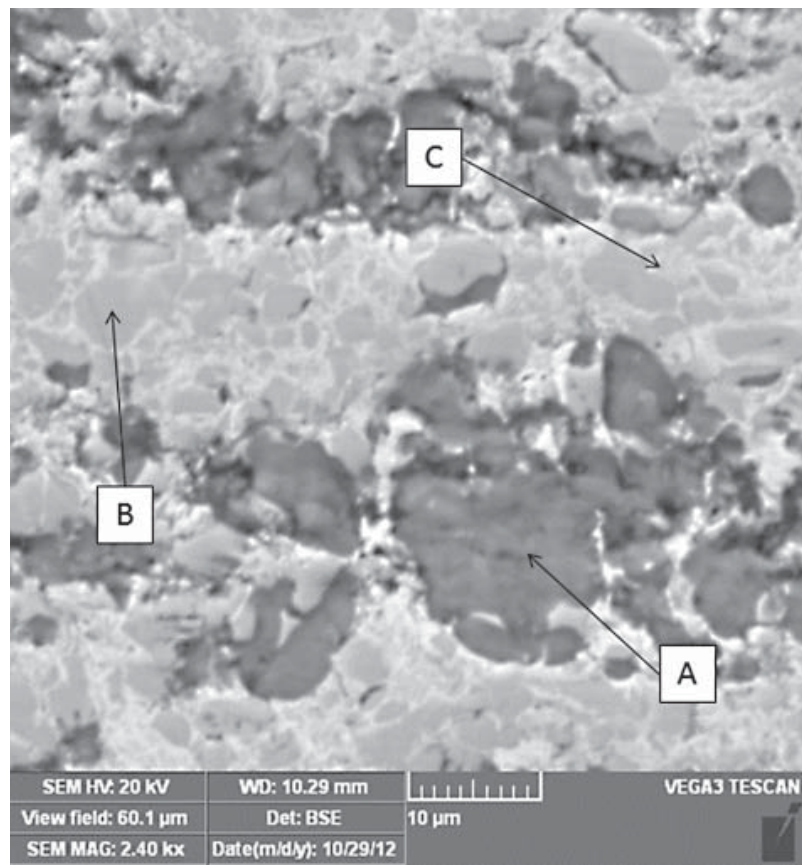

b) detail ze středu vrstvy

Obr. 3. Řez HVOF vrstvou vzorku N1 (pod pouzdrem), a) celkový pohled, b) detail ze středu vrstvy, SEM v zobrazení BSE Fig. 3. Cross-section of HVOF layer of specimen N1 (under bushing), a) whole layer, b) detail from middle of the layer, SEM in backscattered electrons imaging

\section{Řez HVOF vrstvou}

Na Obr. 3a je ukázán řez HVOF vrstvy s neporušeným povrchem v zobrazení odražených elektronů (BSE). Tloušt'ka vrstvy byla určena metalograficky a pohybovala se mezi 250 a $280 \mu \mathrm{m}$. Na rozhraní mezi podkladovým materiálem a vrstvou byla pozorována přítomnost velkých částic, $v$ jednom př́padě došlo dokonce ke tvorbě trhlin vycházejících z této částice. Částice na rozhraní ocel/vrstva neodpovídá složením žádné z očekávaných 
fází a je tvořena především hliníkem a kyslíkem se zvýšenými obsahy vápníku, hořčíku a titanu. Může jít o částice $\mathrm{Al}_{2} \mathrm{O}_{3}$ ukotvené na povrchu v průběhu tryskání před samotným nástřikem. Na Obr. $3 b$ je zobrazen detail vrstvy a v Tab. 2 chemická složení jednotlivých oblastí. Je zřejmé, že nejsvětlejší oblast $(C)$ náleží matrici nástřiku (Ni-Cr), tmavší (B) částicím karbidu chromu (uhlík nebyl do chemického složení započítán) a tmavě šedé oblasti (A) odpovídají oxidům chromu.
Tloušt'ka porušené vrstvy mimo pouzdro byla významně menší a pohybovala se mezi 25 a $30 \mu \mathrm{m}$ (Obr. 4a, v detailu na 4b). Vrstva byla opět tvořena světlými místy fáze $\mathrm{Ni}-\mathrm{Cr}$, tmavšími částicemi $\mathrm{Cr}_{3} \mathrm{C}_{2}$ a tmavými oxidy chromu. Oproti vzorku N1 bylo ve vrstvě výrazněji zastoupeno železo. Na rozhraní ocel/nástřik byly opět detekovány částice $\mathrm{s}$ vysokým obsahem hliníku a křemíku.

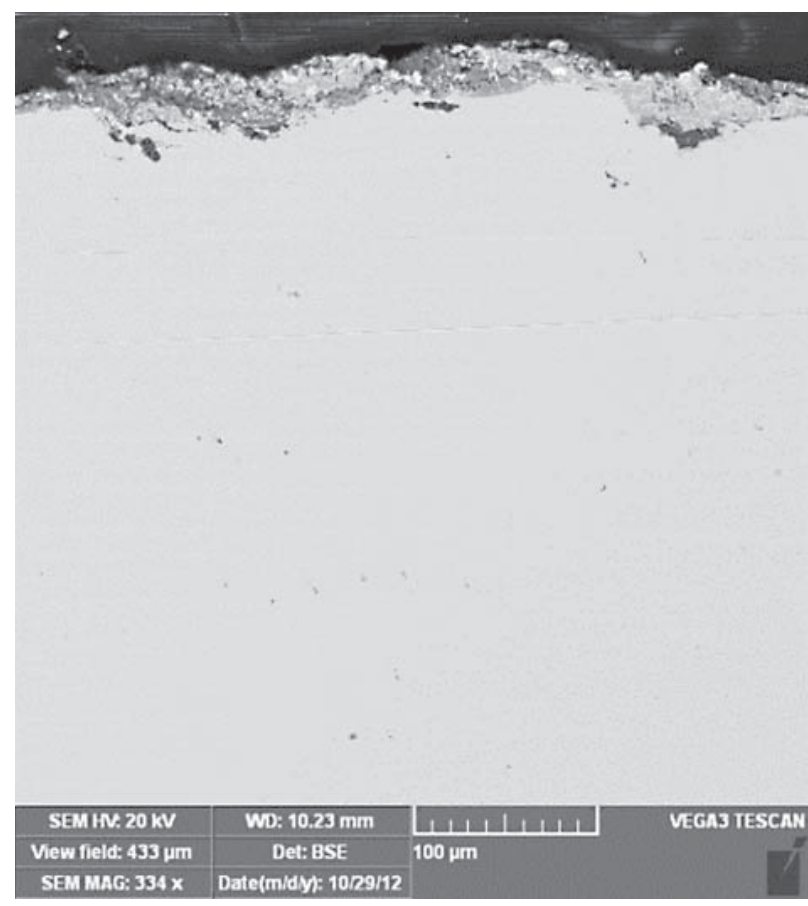

a) celkový pohled

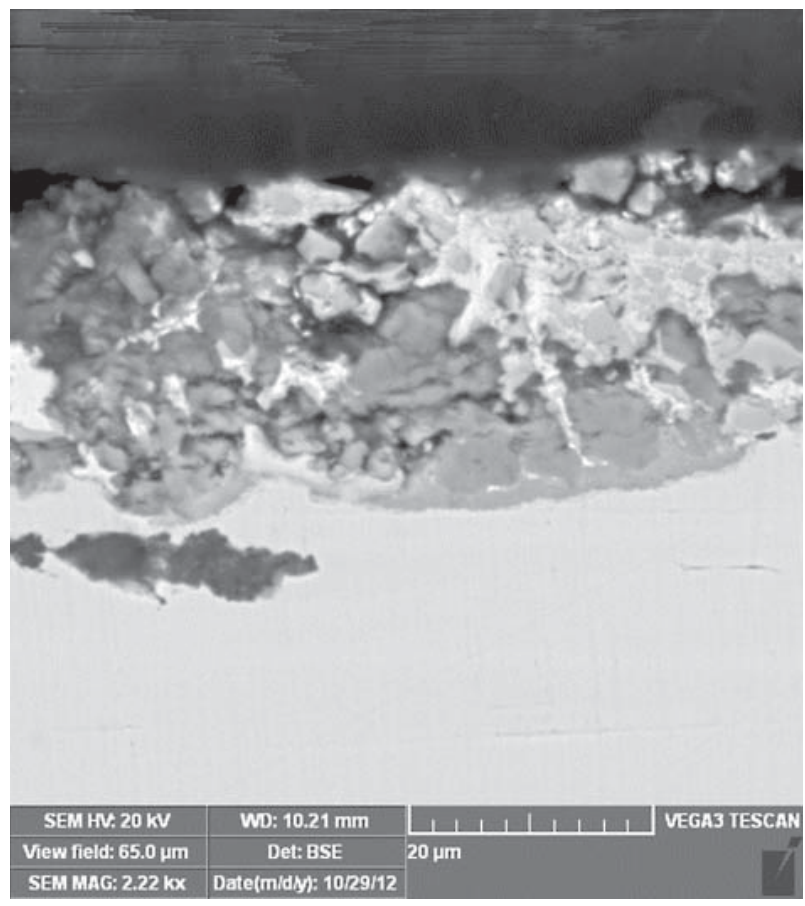

b) detail ze středu vrstvy

Obr. 4. Řez HVOF vrstvou vzorku N2 (mimo pouzdro), a) celkový pohled b) detail ze středu vrstvy, SEM v zobrazení BSE Fig. 4. Cross-section of HVOF layer of specimen N2 (out of bushing), a) whole layer, b) detail from middle of the layer, SEM in backscattered electrons imaging

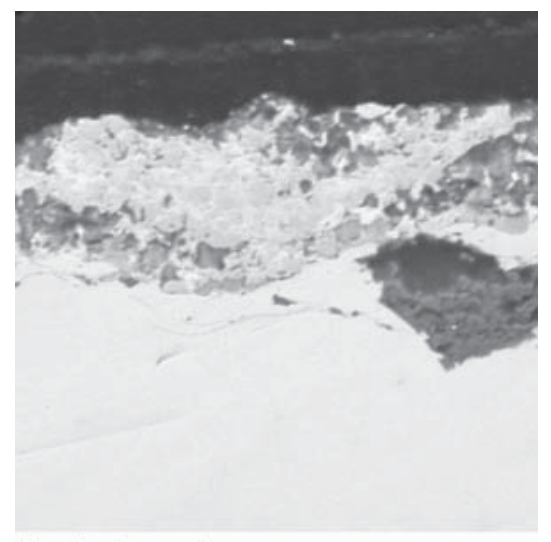

Electron Image 1

a) zobrazení BSE

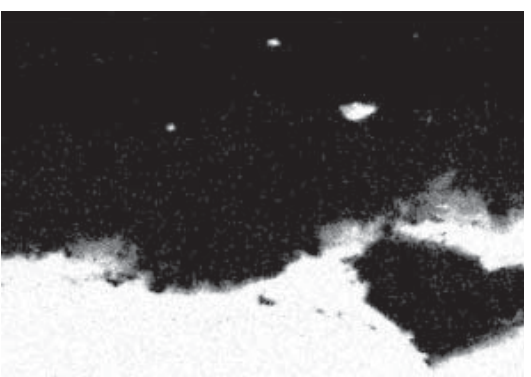

Fe Ka1

b) mapa železa

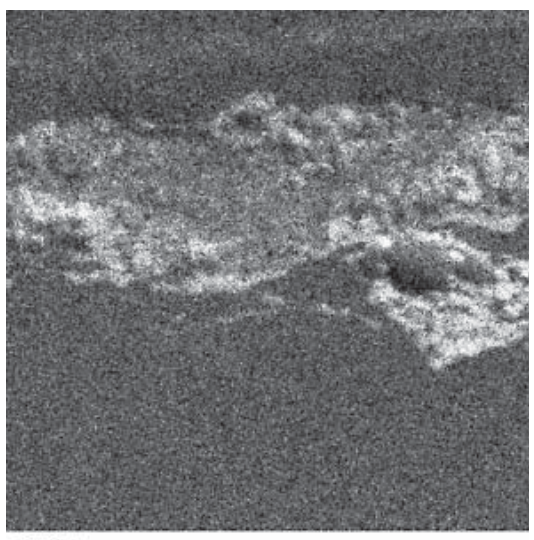

c) mapa kyslíku

Obr. 5. Mapa prvků v řezu HVOF vrstvou vzorku N2 (mimo pouzdro), a) zobrazení BSE b) mapa železa, c) mapa kyslíku

Fig. 5. Cross-section of HVOF layer of specimen N2 (out of bushing), a) BSE imaging, b) map of iron, c) map of oxygen 
Tab. 2. Chemické složení vrstvy vzorku N1 (viz Obr. 4) / Chemical composition of layer of specimen NI (see Fig. 4)

\begin{tabular}{|c|c|c|c|c|c|}
\hline Místo & $\mathbf{O}$ & $\mathbf{F e}$ & $\mathbf{C r}$ & $\mathbf{N i}$ & $\mathbf{S i}$ \\
\hline $\mathrm{A}$ & 27 & - & 70 & 1,9 & 0,6 \\
\hline $\mathrm{B}$ & - & 0,4 & 98 & 1,9 & - \\
\hline $\mathrm{C}$ & - & - & 55 & 45 & - \\
\hline
\end{tabular}

Rozložení železa a kyslíku v degradované vrstvě je znázorněno na Obr. 5. Železo bylo ve vrstvě detekováno pouze na rozhraní s podkladovou ocelí, kde pravděpodobně docházelo $\mathrm{k}$ jeho pomalé difúzi $\mathrm{z}$ materiálu. Př́ítomnost kyslíku byla pozorována v celé vrstvě, nelze však jednoznačně říci, zda náleží oxidu vzniklému během nástřiku či až během následné expozice.

Výrazně menší tloušt'ka vrstvy a absence fáze $\mathrm{Cr}_{3} \mathrm{C}_{2}$ na povrchu poškozeného HVOF povlaku (N2) poukazuje na jeho degradaci vlivem oxidace, pravděpodobně za spoluúčasti vodní páry. V souladu s tímto předpokladem je i absence karbidické fáze $\mathrm{v}$ práškovém vzorku odpadlém z povrchu, která byla zoxidována na $\mathrm{Cr}_{2} \mathrm{O}_{3}$.

Předpokládaným degradačním mechanismem je postupná difúze kyslíku vrstvou a přeměna karbidických částic na oxidické s vyšším objemem. Pro potvrzení tohoto předpokladu je však nutná přesná analýza lehkých prvků (uhlík, kyslík) v řezu vrstvou.

\section{ZÁVĚR}

Práškové vzorky odebrané $\mathrm{z}$ povrchu vřetene byly tvořeny původním nástřikem (fáze $\mathrm{Ni}-\mathrm{Cr}$ a $\mathrm{Cr}_{3} \mathrm{C}_{2}$ ) a oxidy $\mathrm{Cr}_{2} \mathrm{O}_{3}$ a $\mathrm{Fe}_{2} \mathrm{O}_{3}$ vzniklé pravděpodobně jeho oxidací. Povrch základního materiálu X22CrMoV12-1 (bez nástřiku) byl pokryt tenkou vrstvou magnetitu. $\mathrm{V}$ místě degradovaného povlaku byl povrch tvořen sloučeninami na bázi chromu, niklu a kyslíku. Tloušt'ka vrstvy $\mathrm{NiCr}-\mathrm{Cr}_{3} \mathrm{C}_{2}$ se u nepoškozené části pohybovala mezi 250 a $280 \mu \mathrm{m}, \mathrm{v}$ degradované části byla mezi 25 a $30 \mu \mathrm{m}$.
V obou případech byla ve vrstvě analyzována místa odpovídající chemickým složením fázím $\mathrm{Ni}-\mathrm{Cr}, \mathrm{Cr}_{3} \mathrm{C}_{2}$ a $\mathrm{Cr}_{2} \mathrm{O}_{3}$.

Pro hodnocení vhodnosti použití tohoto typu povlaku do podmínek přehřáté páry je nutný rozsáhlejší experimentální program.

\section{LITERATURA}

1. Suegama, P. H., Espallargas, N., Guilemany, J. M., et al. Electrochemical and Structural Characterization of HeatTreated $\mathrm{Cr} 3 \mathrm{C} 2-\mathrm{NiCr}$ Coatings. Journal of The Electrochemical Society 2006, 153 (10), B434-B445.

2. Guilemany, J.M., Espallargas, N., Suegama, P. H. Comparative study of $\mathrm{Cr}_{3} \mathrm{C}_{2}$-NiCr coatings obtained by $\mathrm{HVOF}$ and hard chromium coatings. Corrosion Science 2006, 48 (10), 2998-3013.

3. Ji, G.-C., Li C.-J., Wang, Y.-Y. Microstructural characterization and abrasive wear performance of HVOF sprayed $\mathrm{Cr}_{3} \mathrm{C}_{2}-\mathrm{NiCr}$ coating. Surface \& Coatings Technology 200, 2006, 6749-6757.

4. Mathews, S. J. Erosion-Corrosion of $\mathrm{Cr} 3 \mathrm{C} 2-\mathrm{NiCr} \mathrm{High}$ Velocity Thermal Spray Coatings: Ph.D. Thesis. The University of Auckland, 2004.

5. Kaur, M., Singh, H., Prkash, S. Surface engineering analysis of detonation-gun sprayed $\mathrm{Cr}_{3} \mathrm{C}_{2}-\mathrm{NiCr}$ coating under hightemperature oxidation and oxidation-erosion environments. Surface and Coatings Technology2011,206 (2-3), 530-541.

6. Matthews, S., James, B., Hyland, M. High temperature erosion-oxidation of $\mathrm{Cr}_{3} \mathrm{C}_{2}-\mathrm{NiCr}$ thermal spray coatings under simulated turbine conditions. Corrosion Science 2013, 70, 203-211.

7. Kunioshi, C. T., Correa, O. V., Ramanathan, L. V. ErosionOxidation Behavior of Thermally Sprayed Ni20Cr Alloy and $\mathrm{WC}$ and $\mathrm{Cr}_{3} \mathrm{C}_{2}$ Cermet Coatings. Materials Research 2005, 8(2), 125-129.

8. Sundararajan, T., Kuroda, S., Itagaki, T., Abe, F. Steam Oxidation Resistance of $\mathrm{Ni}-\mathrm{Cr}$ Thermal Spray Coatings on 9Cr-1Mo Steel. Part 1: 80Ni-20Cr. ISIJ International 2003, 43 (1), 95-103.

9. Mann, B. S., Prakash, B. High temperature friction and wear characteristics of various coating materials for steam valve spindle application. Wear 2000, 240, 223-230. 